\title{
Oxidative DNA damage and cellular sensitivity to oxidative stress in human autoimmune diseases ${ }^{\star}$
}

\author{
Saber Bashir, Gilmour Harris, Michael A Denman, David R Blake, Paul G Winyard
}

\begin{abstract}
Objectives-To estimate the extent of genomic DNA damage and killing of lymphocytes by reactive oxygen intermediates in autoimmune diseases.

Methods-8-Oxo-7-hydrodeoxyguanosine (8-oxodG), a promutagenic DNA lesion induced by reactive oxygen intermediates, was measured by high performance liquid chromatography, coupled with electrochemical detection, in hydrolysates of DNA which had been extracted from lymphocyte and polymorphonuclear leucocyte fractions of human blood. In addition, human primary blood lymphocytes stimulated by concanavalin $A$ were assayed for cytotoxicity induced by hydrogen peroxide on day 0 , by assessing cell proliferation during seven days of culture.
\end{abstract}

Results-Constitutive 8-oxodG was detectable (mean (2 SEM) moles 8-oxodG $/ 10^{6}$ moles deoxyguanosine) in DNA isolated from normal human blood lymphocytes (68 (8), $n=26$ ) and polymorphonuclear leucocytes (118 (24), n=24). Lymphocyte DNA from donors with the following inflammatory autoimmune diseases contained significantly higher levels of 8-oxodG than that from healthy donors: rheumatoid arthritis (98 (16)), systemic lupus erythematosus (137 (28)), vasculitis (100 (32)), and Behçet's disease (92 (19)). Lymphocyte 8-oxodG levels in non-autoimmune controls and patients with scleroderma were not significantly different from those of healthy controls. The levels of 8-oxodG were significantly higher in the DNA from normal polymorphonuclear leucocytes than in paired DNA samples from normal lymphocytes, but there were no differences between levels of 8-oxodG in polymorphonuclear leucocytes from normal subjects and the patients studied. Levels of 8-oxodG did not correlate with disease duration, disease severity, or age. Lymphocytes from patients with systemic lupus erythematosus and rheumatoid arthritis, but not those with scleroderma, also showed cellular hypersensitivity to the toxic effects of hydrogen peroxide.

^Parts of this work have previously been presented and published in abstract form: American Association for Cancer published in abstract form: American Association for Cancer December 1991 and Joint Meeting of the Association for Radiation Research and the Society for Free Radical Research, Manchester, England, January 1992 (Int $\mathcal{Y}$ Radiat Biol 1992; 62: 117).
Conclusion-There was increased genomic DNA damage, and increased susceptibility to cytotoxic killing by hydrogen peroxide, in lymphocytes from patients with certain autoimmune diseases. These results might be explained by defective repair of DNA damage or by increased production of reactive oxygen intermediates in inflammation. Although more direct studies are needed, the evidence available favours the former explanation.

(Ann Rheum Dis 1993; 52: 659-666)

Autoimmune diseases are multifactorial in origin and have a strong genetic basis. ${ }^{12}$ Abnormalities of the immune system include hyperactivity of B lymphocytes, which is an early manifestation in mice prone to systemic lupus erythematosus, ${ }^{3}$ and $\mathrm{T}$ cell defects, which may occur relatively late in the disease process. It is therefore possible that disordered B lymphocyte activity combined with a $\mathrm{T}$ cell regulatory disturbance might be the basis for development of autoimmune diseases such as rheumatoid arthritis (RA) and systemic lupus erythematosus (SLE). Regulatory defects of the $T$ cell system resulting from premature loss of long-lived cells as a consequence of increased sensitivity to, and failure to repair, genotoxic damage might thus be important in the pathogenesis of chronic inflammatory autoimmune diseases.

From another point of view, increased somatic mutations in the cells of the immune system might result in the formation of aberrant (forbidden) clones of $\mathrm{T}$ or $\mathrm{B}$ cells, giving rise to autoimmunity in a manner suggested originally in the clonal selection hypothesis of antibody formation of Burnet. ${ }^{4}$ Somatic mutation as a basis for autoimmune disease is an extension of this clonal selection theory of antibody formation. Somatic DNA recombination, as well as specific point mutations involved in normal B cell antibody gene expression during a specific immune response, indicate that somatic mutation is necessary for the normal affinity maturation of antibody specificity during such responses. ${ }^{5} \mathrm{~A}$ single base substitution, however, due to somatic mutation in a specific germ line heavy chain $\mathrm{V}$ region gene coding for part of an antibacterial antibody, has been shown to reduce the ability of that antibody to bind the bacterial antigen and lead to the acquisition of autoantibody specificity. ${ }^{6}$ Perhaps similar mutations might give rise to autoantibody production in human autoimmune disease. 
In previous studies lymphocytes from patients with autoimmune diseases showed increased sensitivity to the toxic effects of $N$-methyl- $N$-nitrosourea ${ }^{7}$ and ionising radiation, ${ }^{8}$ both DNA damaging agents. Furthermore, lymphocytes from patients with autoimmune disease were found to be deficient in repair of $O^{6}$-methylguanine, a product of DNA alkylation and a powerful mutagenic and carcinogenic DNA lesion. ${ }^{9}$

Based on the above considerations, we reasoned that DNA damage by reactive oxygen intermediates might also affect the development of autoimmune diseases. Reactive oxygen intermediates have been shown to cause DNA strand breakage and base damage in target cells. ${ }^{10-13}$ Environmental agents, such as ionising radiation and a variety of chemicals, ${ }^{14}$ as well as normal aerobic cellular metabolism, ${ }^{15}$ can generate reactive oxygen intermediates, which have therefore been implicated in carcinogenesis. ${ }^{16}$ In chronic inflammatory diseases, such as RA and SLE, reactive oxygen intermediates released from phagocytic cells at the site of injury may cross cell membranes and react with nuclear DNA. $^{17}$ A major specific product of oxidative damage to DNA is 8-oxo-7-hydrodeoxyguanosine (8-oxodG), formed by the reaction of the hydroxyl radical $\left({ }^{\circ} \mathrm{OH}\right)$ at the C8 position of deoxyguanosine. ${ }^{19-21}$ This DNA adduct is mutagenic ${ }^{22}$ and is produced by agents that are mutagenic, carcinogenic, and cytotoxic. ${ }^{23-25} \mathrm{~A}$ sensitive technique is available for the measurement of 8-oxodG by high performance liquid chromatography with electrochemical detection (HPLC-EC) ${ }^{26}$

The rate of repair of a promutagenic base lesion in cellular DNA is important in determining the rate of mutation, ${ }^{27}$ as cell division by unrepaired cells can result in direct miscoding during DNA replication. We suggest that increased susceptibility to oxidative DNA damage, coupled with defective repair of such damage, is an important cause of human autoimmune disorders. To test for increased susceptibility to oxidative DNA damage we measured the DNA base adduct, 8-oxodG, in the peripheral blood mononuclear cells of patients with various autoimmune diseases, and the sensitivity of human lymphocytes to oxidative stress induced by $\mathrm{H}_{2} \mathrm{O}_{2}$.

\section{Patients and methods}

PATIENTS AND HEALTHY SUBJECTS IN 8-oxodG STUDY

Levels of 8-oxodG were measured in 155 subjects in the following categories:

1 Healthy controls Twenty seven healthy laboratory staff (eight women, $19 \mathrm{men}$ ), median age 31 years (range 25-64).

2 Non-autoimmune controls Twenty fou patients (12 women, 12 men) with miscellaneous non-autoimmune conditions, such as pneumonia, myocardial infarction, and osteoarthritis, median age 36 years (range $18-87$ ). Disease duration $<1$ to 18 years (mean $2 \cdot 7$ years)
3 Controls $\geqslant 38$ years old Twenty three subjects (eight women, 15 men), median age 47 years (range $38-87$ ), were admitted to this category from groups 1 and 2 above.

4 Controls $<38$ years old Twenty eight subjects (12 women, 16 men), median age 31 years (range 18-37), were entered into this category from groups 1 and 2 above.

5 Systemic lupus erythematosus Twenty one patients (16 women, five men), median age 40 years (range 18-74), satisfying Arthritis and Rheumatism Association criteria. ${ }^{28}$ Disease duration two to 16 years (mean 7.6 years). Disease severity was assessed by scoring of clinical and laboratory parameters. ${ }^{29}$ In summary, these were mouth ulcers, skin lesions, photosensitivity, Raynaud's, serositis, arthritis, renal disease, central nervous system disease, pulmonary disease, autoimmune haematological abnormalities, DNA binding autoantibodies, and hypocomplementaemia.

6 Rheumatoid arthritis Thirty four patients (16 women, 18 men), median age 60 years (range 36-84), satisfying the diagnostic criteria of Ropes et al. ${ }^{30}$

7 Behçet's disease Sixteen patients (eight women, eight men), median age 45 years (range 21-58), with established diagnostic features. ${ }^{31}$ Disease duration three to 22 years (mean 12.7 years).

8 Scleroderma Eighteen patients (seven women, $11 \mathrm{men}$ ), median age 46 years (range 22-66), who fulfilled the diagnostic criteria of Masi et al. ${ }^{32}$

9 Vasculitis Fifteen patients (eight women, seven men), median age 58 years (range 26-73). Disease duration one to 18 years (mean 4.6 years)

PATIENTS AND HEALTHY SUBJECTS IN THE CYTOTOXICITY STUDY

Seventy seven patients were studied by the $\mathrm{H}_{2} \mathrm{O}_{2}$ cytotoxicity assay. Where possible, these patients were the same as those in whom 8-oxodG levels were determined, but this was constrained by the relatively large blood volume required for the two assays. The inclusion criteria for the four groups studied for cytotoxicity were the same as for the corresponding groups in the 8-oxodG study and the details of the groups are given below.

1 Healthy controls Twenty three healthy laboratory staff (eight women, 15 men), median age 35 years (range 22-59). Ten of these subjects also formed part of the healthy control group in which 8-oxodG levels were measured.

2 Systemic lupus erythematosus Twenty two patients ( 12 women, 10 men), median age 36 years (range 23-52). Disease duration two to 15 years (mean 6.4 years). Nine of these subjects were also in the 8-oxodG study.

3 Rheumatoid arthritis Twenty patients (13 women, seven men), median age 61.5 years (range 30-73). Disease duration five to 18 years (mean 10.6 years). Seven of these subjects were also in the 8-oxodG study. 
4 Scleroderma Twelve patients (five women, seven men), median age 55 years (range 42-77). Ten of these subjects were also in the 8-oxodG study.

Most of the patients were receiving some form of drug treatment. In particular, all but two of the patients with SLE were receiving prednisolone, but in doses not exceeding 10 mg daily, and they had not had intravenous methylprednisolone in the six months preceeding the study. Some patients with RA were receiving disease modifying antirheumatic drugs and simple non-steroidal antiinflammatory drugs. All blood samples were obtained (with approval of the ethical committee of Northwick Park Hospital, UK) from patients under the care of the Division of Connective Tissue Diseases, Clinical Research Centre, Northwick Park Hospital, UK, with the exception of the blood samples from patients with scleroderma, which were obtained from the rheumatology clinic at the Royal Free Hospital, London, UK.

\section{DETERMINATION OF 8-OXO-7-}

HYDRODEOXYGUANOSINE IN BLOOD CELL DNA Human mononuclear cells and granulocytes were isolated by density centrifugation of about $50 \mathrm{ml}$ of fresh heparinised human blood. Erythrocytes were removed from the granulocyte fraction by hypotonic lysis. From each group of cells, DNA was isolated by the phenol method. ${ }^{33}$ Great care was taken to avoid artificial induction of 8-oxodG, by using fresh peroxide-free phenol (BDH, Poole, Dorset, UK) and the antioxidants $m$-cresol and 8-hydroxyquinoline (BDH, Poole, Dorset, UK). Isolated DNA was fully digested to the nucleoside level, using the enzymes endonuclease (from $N$ crassa), DNase I (from bovine pancreas), phosphodiesterase (from $C$ atrox), and alkaline phosphatase (from $E$ coli), obtained from Sigma, Poole, UK. ${ }^{34}$ The resulting deoxynucleoside mixture was analysed by HPLC coupled with an amperometric electrochemical detector using a modification ${ }^{35}$ of the method of Floyd et al..$^{26}$

Apparatus and conditions were: fastreciprocating pump (model number 351, Applied Chromatography Systems, Macclesfield, Cheshire, UK), column: Shandon (Runcorn, Cheshire, UK) Hypersil ODS $(0.46 \times 25 \mathrm{~cm})$; eluant: $4 \%$ methanol in HPLC grade water containing $12.5 \mathrm{mM}$ citric acid, $25 \mathrm{mM}$ sodium acetate, $30 \mathrm{mM} \mathrm{NaOH}$, $10 \mathrm{mM}$ acetic acid, pH 5.1; flow $1 \mathrm{ml} / \mathrm{min}$; ultraviolet detector (Applied Chromatography Systems) $290 \mathrm{~nm}$; electrochemical detector, Bioanalytical Systems model LC-4B, $700 \mathrm{mV}$ (oxidation) (Biotech, Luton, Beds, UK). The molar ratio of 8-oxodG to deoxyguanosine in each DNA sample was determined in duplicate based on the peak height of authentic 8-oxodG by electrochemical detection and the absorption at $290 \mathrm{~nm}$ of deoxyguanosine. The authentic 8-oxodG standard was synthesised from deoxyguanosine as previously described, ${ }^{36}$ and the structure was confirmed by fast atom bombardment-mass spectrometry.

\section{CYTOTOXICITY ASSAY}

Human mononuclear cells were obtained for culture from peripheral blood by density gradient separation after layering onto 'Histopaque-1077' (Sigma, Poole, UK) under sterile conditions. Full details of the preparation and measurement of the proliferative response to concanavalin $\mathrm{A}$ in culture have been described. ${ }^{37}$ Briefly, lymphocytes were cultured in a $3 \mathrm{ml}$ volume $\left(0.5 \times 10^{6}\right.$ cells/ml) in RPMI 1640 culture medium supplemented with $5 \%$ fetal calf serum and $0.05 \mathrm{mM}$ 2-mercaptoethanol in flat bottom 'Linbro' tissue culture plates. The addition of concanavalin A $(4 \mu \mathrm{g} / \mathrm{ml})$ at the start of the culture period induced proliferation of responsive cells in these cultures, assessed by microscopical cell counting in a haemocytometer on day seven, the time of maximal increase in cell numbers. Cells were incubated at $37^{\circ} \mathrm{C}$ in an atmosphere of $5 \% \quad \mathrm{CO}_{2}$. Hydrogen peroxide was added at different concentrations at the beginning of culture. In preliminary experiments the half life of $\mathrm{H}_{2} \mathrm{O}_{2}$ under the conditions stated above was 24 minutes and, therefore, the medium was not removed after the $\mathrm{H}_{2} \mathrm{O}_{2}$ addition. The cell cultures were not re-fed with the culture medium over the seven day period. The results are given as the mean of each group and are expressed as the percentage growth of cells in control cultures not exposed to $\mathrm{H}_{2} \mathrm{O}_{2}$, growth being the difference in cell number after seven days. Only the results for control cells which more than doubled in number during seven days of culture were included.

\section{STATISTICAL ANALYSIS}

All statistical analyses were done with the non-parametric Mann-Whitney $U$ test and Spearman's rank correlation coefficient. Values are stated as the mean (SEM) or mean (2 SEM), as indicated.

\section{Results}

The adduct, 8-oxodG, was measured separately in the DNA from lymphocytes and polymorphonuclear leucocytes, isolated from the peripheral blood of patients with a variety of chronic inflammatory diseases and from control subjects. 8-oxodG was detected at a level of between about 30 and 300 moles 8 -oxodG per $10^{6}$ moles deoxyguanosine in all the samples analysed. Figure 1A shows a typical HPLC-EC analysis of the deoxynucleoside mixture, produced from the digested DNA from lymphocytes. 8-oxodG is one of the main electrochemically active analytes under the detection conditions used, though other unidentified peaks were also present. Peak identity was confirmed by the retention time (fig 1C), spiking the hydrolysed DNA sample with authentic 8-oxodG standard (fig 1B), and by determining the voltammogram of the relevant peak in a sample of hydrolysed lymphocyte DNA. The within-batch coefficient of variation for the assay was $3 \cdot 6 \%$ and the batch to batch coefficient of variation was $10 \cdot 95 \%$. 
A

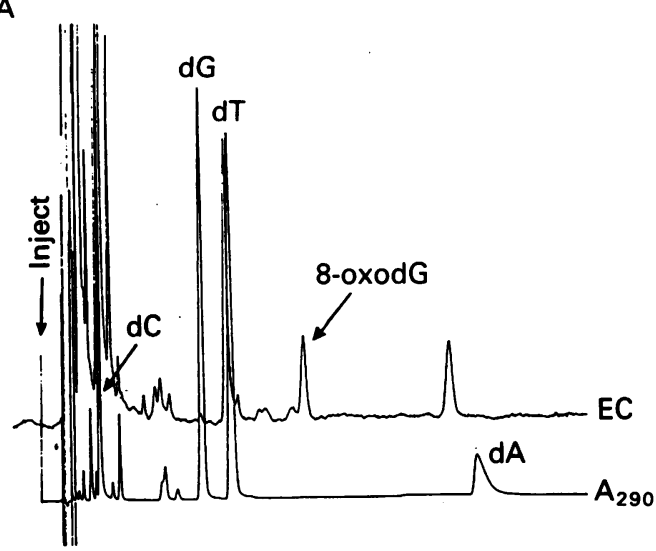

B

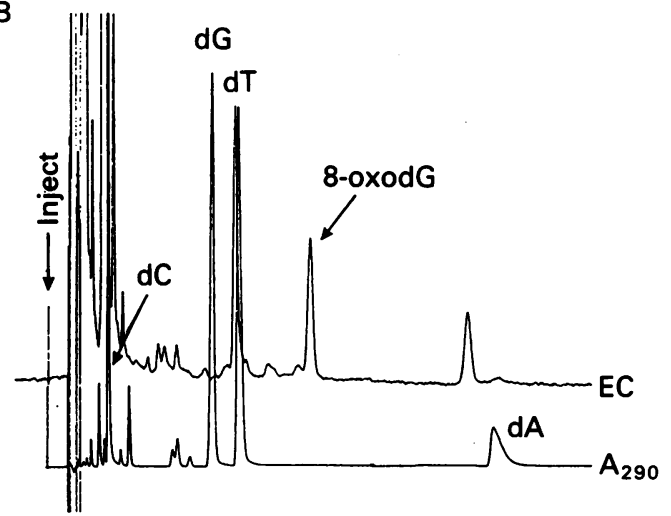

C

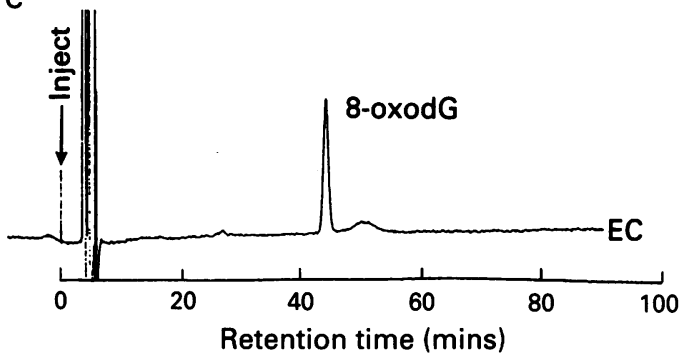

Figure 1 Detection of 8-oxodG in a normal human lymphocyte DNA hydrolysate by high performance liquid chromatography with electrochemical detection (HPLC-EC). The electrochemical detector response $\left(f_{s d}=2 \mathrm{nA}\right)$ and absorption at $290 \mathrm{~nm}\left(A_{290}\right)$ were recorded. (A) Sample of DNA hydrolysed; (B) sample of DNA hydrolysed and spiked with 3.07 pmoles of 8-oxodG standard; $(C)$ authentic standard of 8.85 pmoles of 8-oxodG. The detection limit was 50 fmol (signal to noise ratio $\geqslant 3)$. $d C=$ deoxycytidine; $d G=$ deoxyguanosine; $d T=$ deoxythymidine; $d A=$ deoxyadenosine.

Lymphocyte DNA from donors with the inflammatory autoimmune diseases RA, SLE, vasculitis, and Behçet's disease contained significantly raised levels of 8-oxodG (fig 2) in comparison with healthy donors. An exception to this was lymphocyte DNA from patients with scleroderma, a disease associated with autoimmunity, which showed levels of 8-oxodG within the healthy donor range. There was no significant difference between levels in healthy donors and levels in patients with non-autoimmune diseases.

Levels of 8-oxodG were greatly increased in the group with SLE, showing a wide range of values. Therefore, in this group, a further analysis was carried out to establish whether levels of 8-oxodG correlated with either clinical disease severity or disease duration. There was no significant correlation $(p>0.05)$ between disease severity (see 'Patients and methods') and either lymphocyte 8-oxodG $(r=-0 \cdot 38$, $\mathrm{n}=13$ ) or polymorphonuclear leucocyte 8-oxodG $(r=0.45, n=17)$. Furthermore, in the group with SLE, there was no correlation between disease duration and 8-oxodG levels in lymphocytes $(\mathrm{r}=0.14, \mathrm{n}=13)$ or polymorphonuclear leucocytes $(r=0 \cdot 25, n=17)$.

In the healthy control group there was a weak correlation $(p=0.03)$ between the levels of 8-oxodG in lymphocyte DNA and levels in polymorphonuclear leucocyte DNA. There was no correlation, however, between these variables in any of the other groups studied (table). The mean level of 8-oxodG was significantly higher in polymorphonuclear leucocyte DNA than in lymphocyte DNA in the controls and the groups with RA or scleroderma, but not in patients with SLE, vasculitis, or Behçet's disease (table). There was no significant difference on comparison of the mean level of 8-oxodG in healthy control polymorphonuclear leucocytes with that from the group with non-autoimmune diseases or from any of the groups with an autoimmune disease.

The healthy controls and the control group with non-autoimmune disease were matched for age with the group with SLE, SLE being an autoimmune disease which often presents in relatively young patients. To obtain a control group which was matched for age with the groups with RA and vasculitis, subjects from both the healthy and non-autoimmune control groups who were $\geqslant 38$ years of age were combined (table). There was a significant increase in lymphocyte 8-oxodG levels in both RA and vasculitis with respect to the pooled control group aged $\geqslant 38 \quad(p=0.005$ and $p=0.015$ respectively). There was no correlation within any of the groups, including a pooled group of all the controls (healthy controls plus non-autoimmune controls), between age and lymphocyte 8-oxodG levels. There was, however, a weak correlation between age and 8-oxodG levels in polymorphonuclear leucocytes in two of the groups (healthy controls, $p=0.05$; patients with $R A$, $p=0.04)$. When our healthy control group was analysed further, by dividing it into smokers and non-smokers, there was no significant difference between the groups in 8-oxodG levels in either lymphocytes or polymorphonuclear leucocytes. Also, when the subjects were grouped according to sex within each of the groups studied, there was no statistically significant difference between men and women in the level of 8-oxodG from lymphocytes or polymorphonuclear leucocytes.

To determine if autoimmune patients showed cellular hypersensitivity to oxidative damage the growth of cultured peripheral blood lymphocytes in response to concanavalin A, ${ }^{37}$ after initial damage by $\mathrm{H}_{2} \mathrm{O}_{2}$, was measured. In agreement with earlier studies ${ }^{8}$ there was no significant difference in the magnitude of the response to concanavalin A in autoimmune disease $v$ control lymphocytes in the absence of $\mathrm{H}_{2} \mathrm{O}_{2}$. The growth of lymphocytes from patients with RA and SLE showed (fig 3 ) increased sensitivity to the 


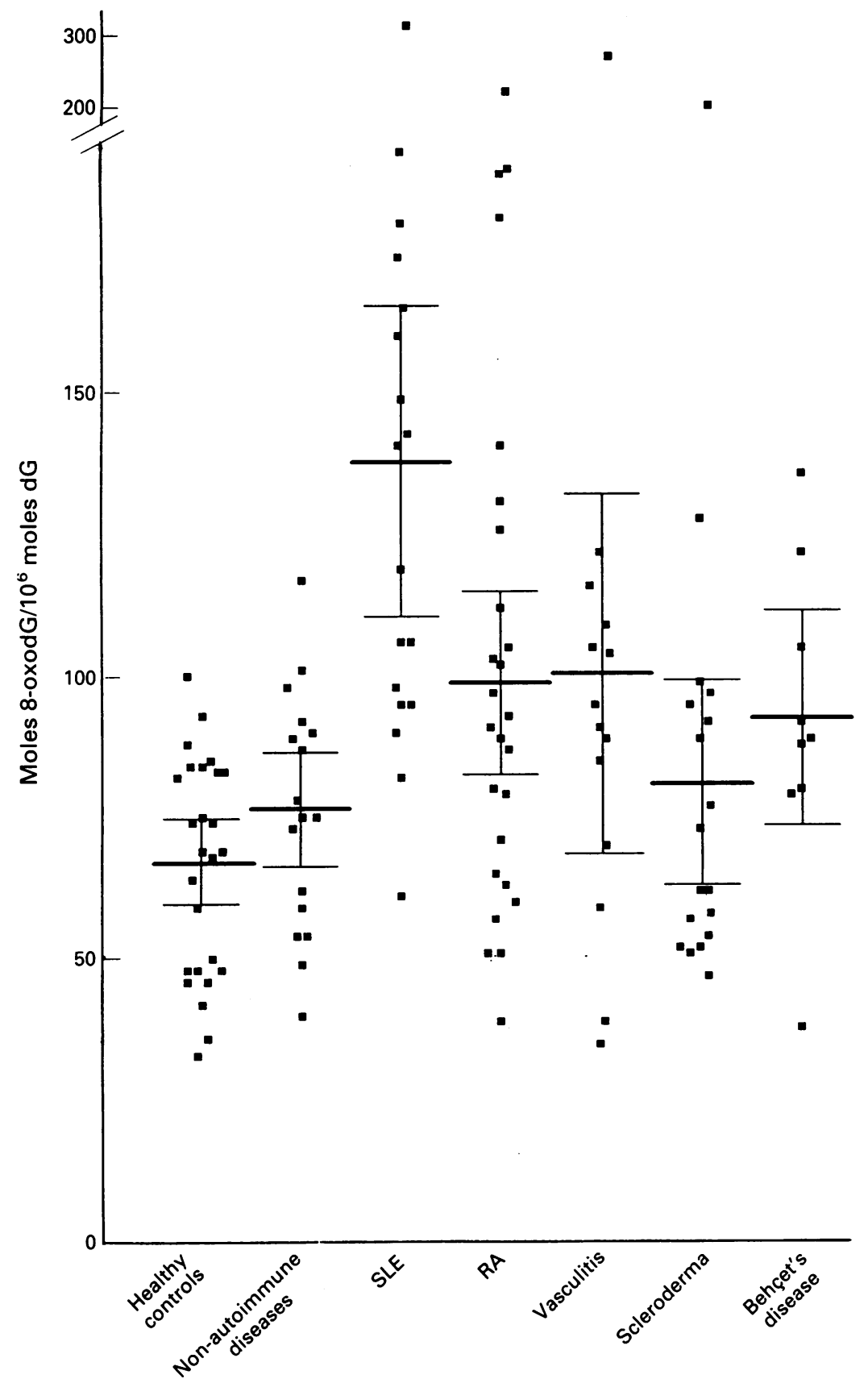

Figure 2 Levels of 8-oxodG in lymphocyte DNA from healthy control subjects, patients with non-autoimmune diseases, and patients with systemic lupus erythematosus (SLE), rheumatoid arthritis $(R A)$, vasculitis, scleroderma, and Behçet's disease. Results are expressed as the number of moles of 8-oxodG per $10^{6}$ moles of $d G$ (mean (2 SEM)) and each data point represents the mean of duplicate analyses. $p=0.0001$ (controls $\mathrm{v} S L E$ ), $p=0.001$ (controls $\vee R A$ ), $p=0.006$ (controls $\vee$ vasculitis), and $p=0.01$ (controls $\vee$ Behçet's disease) using a non-parametric Mann-Whitney U test.

inhibitory effects of $\mathrm{H}_{2} \mathrm{O}_{2}$ on cell growth in response to concanavalin $\mathrm{A}$, compared with healthy controls. Of the autoimmune diseases studied, scleroderma was exceptional in showing normal sensitivity of lymphocytes to $\mathrm{H}_{2} \mathrm{O}_{2}$. At a concentration of $\mathrm{H}_{2} \mathrm{O}_{2}$ of $0.3 \mathrm{mmol} / \mathrm{l}$ or greater, lymphocytes from patients with SLE or RA were significantly more sensitive than normal control lymphocytes (fig 3). There was no obvious relation between the drugs that patients were receiving and either lymphocyte sensitivity to $\mathrm{H}_{2} \mathrm{O}_{2}$ or 8-oxodG levels.

\section{Discussion}

These results show that the mean level of 8-oxodG in lymphocyte DNA from donors with SLE, RA, and vasculitis was greater than in normal healthy control subjects. The levels of 8-oxodG were also higher in Behçet's disease. Although this condition is characterised by recurring inflammation, it is not strictly autoimmune in nature, but may be a response to persistent infection with herpes virus, ${ }^{38}$ which may impair DNA repair. Reduced repair proficiency of $O^{6}$-methylguanine, a powerful promutagenic DNA lesion, and increased cellular sensitivity to alkylation damage as well as ionising radiation, has also been reported ${ }^{7-9}$ in blood lymphocytes from patients with these diseases, including Behçet's disease. Interestingly, the levels of 8-oxodG in lymphocytes from patients with scleroderma, a disease associated with autoimmunity, coincided with levels in lymphocyte DNA from healthy controls, while previous studies also showed proficient repair of $O^{6}$-methylguanine in lymphocyte DNA from these patients. ${ }^{9}$ Repair of damage to target cells by ionising radiation alters the DNA quaternary structure, as shown by its reduced buoyant density in sucrose gradients owing to unwinding of the DNA molecule. ${ }^{8}$ Spontaneously increased DNA unwinding has been found in the blood mononuclear cells from patients with RA when compared with healthy controls. ${ }^{39}$ This suggests that there may be a general deficiency in several types of DNA repair in lymphocytes from autoimmune patients.

Increased rates of cell division by cells with DNA damage after exposure to genotoxic agents might produce increased rates of somatic mutation which may be involved in the pathogenesis of these autoimmune diseases. Such a view has recently been advanced in relation to chemical carcinogenesis. ${ }^{14}$ In vitro, replication of an oligodeoxynucleotide template containing 8-oxodG resulted in the directed misreading of pyrimidine residues neighbouring the lesion, ${ }^{22}$ or in the preferential incorporation of deoxyadenosine and deoxycytidine, selectively, opposite the 8-oxodG residue of a synthetic DNA template. ${ }^{40}$ There is evidence that 8 -oxodG is a repairable DNA base lesion in both prokaryotes and eukaryotic cells. After the induction of 8-oxodG by high dose irradiation of mice a time dependent decrease in 8-oxodG levels was seen, which was interpreted as indicative of repair. ${ }^{41} \mathrm{An}$ endonuclease that specifically excises 8-oxodG from DNA has been isolated from $E \operatorname{coli}^{42}$ and human polymorphonuclear leucocytes. ${ }^{43}$ The most predominant mutation shown after $\gamma$ irradiation of double stranded phage M13 DNA was transversion of $C: G$ to $G: C$, probably due to the DNA lesion of 8 -oxodG. ${ }^{44}$

A fivefold variation has been reported in levels of 8-oxodG in lymphocyte DNA from normal men, ${ }^{45}$ though the actual levels of 8-oxodG were not stated. Levels of 8-oxodG in normal human breast tissue $e^{46}$ and human polymorphonuclear leucocytes ${ }^{47}$ were similar to the levels in healthy donor cells reported here. In contrast, 8-oxodG was increased in breast ductal carcinoma DNA, ${ }^{46}$ perhaps owing to increased oxidative DNA damage, 
8-Oxo-7-hydrodeoxyguanosine (8-oxodG) levels in paired samples of lymphocyte and polymorphonuclear leucocyte (PMN) DNA from healthy controls and various disease groups. Results are given as the mean (2 SEM). The number of subjects is shown in parentheses

\begin{tabular}{|c|c|c|c|c|}
\hline Group & $\begin{array}{l}\text { Lymphocyte 8-oxodG } \\
\text { (moles 8-oxodG/10 moles } d G)\end{array}$ & $\begin{array}{l}\text { PMN 8-oxodG } \\
\left(\text { moles 8-oxod } G / 10^{6} \text { moles } d G\right)\end{array}$ & $\begin{array}{l}\text { Mann-Whitney U test } \\
\text { for lymphocyte } \mathrm{v} \\
P M N 8 \text {-oxodG } \\
\text { (p value) }\end{array}$ & $\begin{array}{l}\text { Correlation coefficient }(r) \\
\text { for lymphocyte } \mathrm{v} \\
\text { PMN 8-oxodG } \\
\text { ( } p \text { value) }\end{array}$ \\
\hline Healthy controls & $\begin{array}{l}68(8) \\
(26)\end{array}$ & $\begin{array}{l}118(24) \\
(24)\end{array}$ & 0.0001 & $\begin{array}{l}0.46 \\
(p=0.03)\end{array}$ \\
\hline Non-autoimmune controls & $\begin{array}{l}76(10) \\
(17)\end{array}$ & $\begin{array}{l}118(34) \\
(23)\end{array}$ & 0.0504 & $\begin{array}{l}0.01 \\
(\mathrm{NS})\end{array}$ \\
\hline Pooled controls $\geqslant 38$ years old & $\begin{array}{l}69(8) \\
(19)\end{array}$ & $\begin{array}{l}126(28) \\
(20)\end{array}$ & 0.0001 & $\begin{array}{l}0.05 \\
(\mathrm{NS})\end{array}$ \\
\hline Pooled controls $<38$ years old & $\begin{array}{l}71(9) \\
(24)\end{array}$ & $\begin{array}{l}112(29) \\
(27)\end{array}$ & 0.0131 & $\begin{array}{l}0 \cdot 31 \\
(\mathrm{NS})\end{array}$ \\
\hline SLE & $\begin{array}{l}137(28) \\
(18)\end{array}$ & $\begin{array}{l}126(28) \\
(21)\end{array}$ & NS & $\begin{array}{l}0 \cdot 20 \\
(\mathrm{NS})\end{array}$ \\
\hline RA & $\begin{array}{l}98(16) \\
(26)\end{array}$ & $\begin{array}{l}138(28) \\
(34)\end{array}$ & 0.044 & $\begin{array}{l}0 \cdot 36 \\
(\mathrm{NS})\end{array}$ \\
\hline Vasculitis & $\begin{array}{l}100(32) \\
(14)\end{array}$ & $\begin{array}{l}149(68) \\
(14)\end{array}$ & NS & $\begin{array}{l}0 \cdot 20 \\
(\mathrm{NS})\end{array}$ \\
\hline Scleroderma & $\begin{array}{l}81(18) \\
(18)\end{array}$ & $\begin{array}{l}139(44) \\
(18)\end{array}$ & 0.0236 & $\begin{array}{l}0 \cdot 14 \\
(\mathrm{NS})\end{array}$ \\
\hline Behçet's disease & $\begin{array}{l}92(19) \\
(9)\end{array}$ & $\begin{array}{l}96(18) \\
(16)\end{array}$ & NS & $\begin{array}{l}0 \cdot 10 \\
(\mathrm{NS})\end{array}$ \\
\hline
\end{tabular}

though reduced repair proficiency by the tumour tissue could not be ruled out. Fraga et al found a correlation between the age of rats and the levels of 8-oxodG in DNA from some organs. ${ }^{48}$ However, age does not seem significantly to affect the levels of 8-oxodG in human blood lymphocytes. Moreover, we found no evidence that 8-oxodG levels are higher in smokers than in non-smokers. Although an increase in 8-oxodG in human peripheral

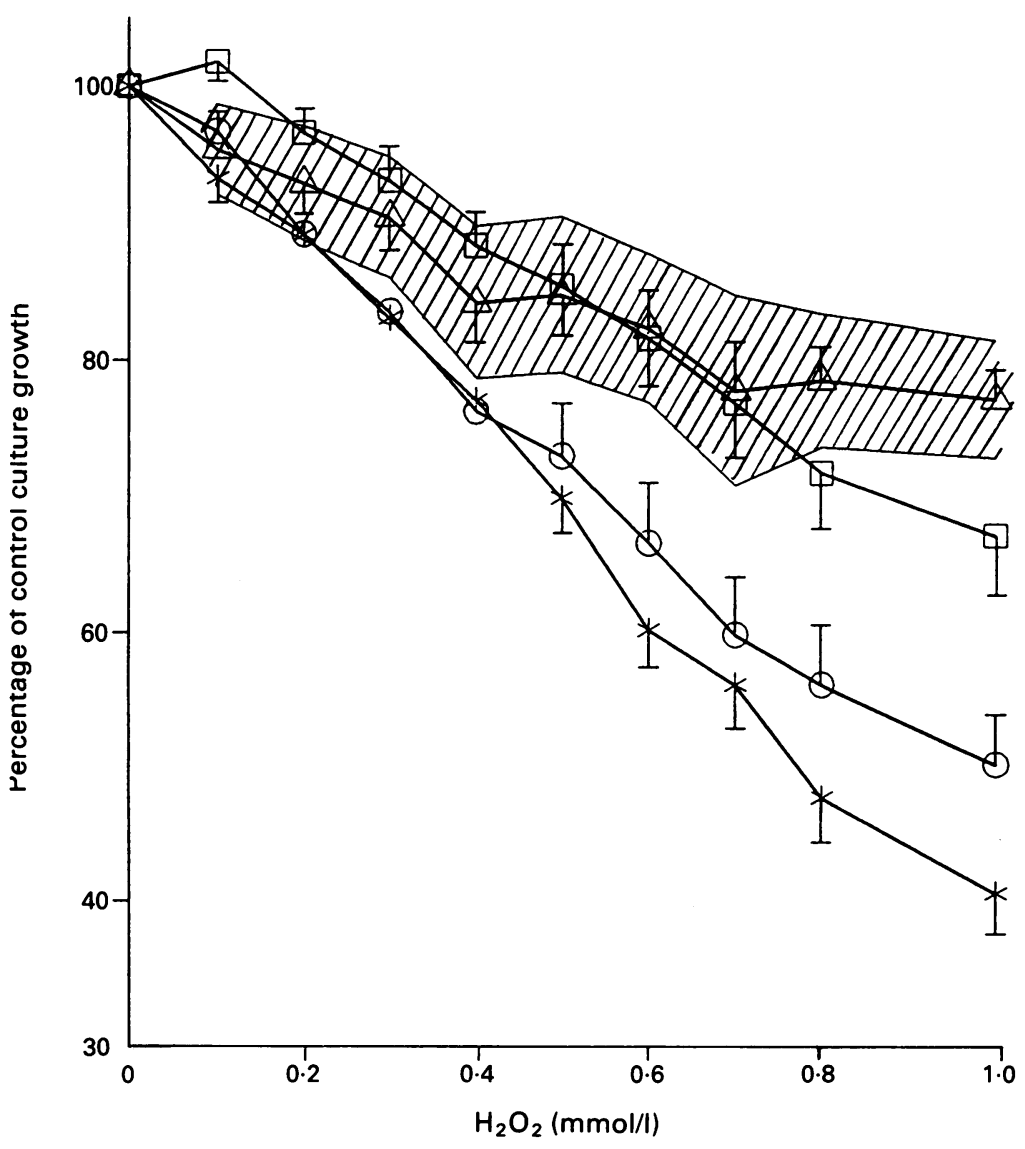

Figure 3 Inhibitory effect of varying concentrations of $\mathrm{H}_{2} \mathrm{O}_{2}$ on the growth of human lymphocytes in response to concanavalin $A$, expressed as percentage of the growth of untreated culture. The mean (SEM) growth curve for each disease group is shown. The shaded area represents the $95 \%$ confidence limits for the healthy controls. $\triangle=$ controls $(n=23) ; \square=$ scleroderma $(n=12) ; \bigcirc=R A(n=20) *=S L E(n=22)$ blood leucocyte DNA was seen immediately after smoking, ${ }^{49}$ there are no reports of a long term increase in smokers.

Systemic lupus erythematosus and RA are inflammatory diseases in which the production of the superoxide anion radical $\left(\mathrm{O}_{2}{ }^{--}\right)$is increased in inflammatory cells such as polymorphonuclear leucocytes. In these diseases an increased incidence of chromosome aberrations and sister chromatid exchanges has been reported in mitogen stimulated lymphocytes, ${ }^{5051}$ possibly resulting from induced DNA damage. The increased extents of oxidative cellular DNA damage, indicated by raised levels of 8-oxodG in lymphocyte DNA, might have resulted from the associated inflammation in the diseases studied here. Such active inflammation would result in increased free radical formation at inflammatory sites. There is, however, no good evidence available to show that chronic inflammation can induce increased levels of 8-oxodG in target tissues, though non-specific DNA damage, such as strand breaks, has been described. ${ }^{52}$ Furthermore, although polymorphonuclear leucocytes accumulate at the site of inflammation, and in vitro activation of polymorphonuclear leucocytes induces 8-oxodG in the cell's own $\mathrm{DNA}^{47}$ and in previously isolated DNA, ${ }^{53}$ no significant difference in polymorphonuclear leucocyte 8-oxodG levels was seen between the various disease groups studied here. No increase, above control levels, of the 8-oxodG content was found in the blood lymphocyte or polymorphonuclear leucocyte DNA in either ulcerative colitis or Crohn's disease (manuscript in preparation), where extensive and severe inflammation of the affected colon occurs. Thus the disease specificity of the increase in 8-oxodG suggests that the increase is not simply a consequence of inflammation.

The mechanism of production of 8-oxodG in cellular DNA is not known, but might result from exposure to environmental agents, such as ultraviolet and ionising radiation, as well as a wide range of chemical agents ${ }^{14}$ and products 
of normal endogenous aerobic metabolism. Attempts in this laboratory to induce 8-oxodG in the DNA of cultured, intact primary blood and spleen lymphocytes by $\mathrm{H}_{2} \mathrm{O}_{2}$ and radiation, even at very high dosage, have been unsuccessful, in direct contrast with experiments using previously isolated DNA. ${ }^{2021}$ Also, 8-oxodG was not induced above background levels in rat hepatocytes treated with bleomycin, ${ }^{54}$ an antitumour antibiotic thought to involve the formation of a reactive oxygen intermediate, possibly the hydroxyl radical. Induction of 8-oxodG in established cell lines has been reported after exposure to $x$ rays $^{41}$ or $\mathrm{H}_{2} \mathrm{O}_{2},{ }^{12}{ }^{55}$ but very high doses were required. Whatever the mechanism(s) involved, most human peripheral blood lymphocytes are long lived cells with long intermitotic times, which would thus allow for the accumulation of 8-oxodG in their cellular DNA even when acquired slowly. In contrast, polymorphonuclear leucocytes are short-lived cells with a half life of about six hours in human blood. It therefore seems more likely that deficient repair, rather than increased damage, accounts for the increased levels of 8-oxodG in the peripheral blood lymphocytes of the patients studied here. Others have previously suggested that patients with SLE are defective in 8-oxodG repair, based on the analysis of urinary 8-oxodG. ${ }^{56}$

Hydrogen peroxide inhibited the proliferation of concanavalin A stimulated cultured human peripheral blood $\mathrm{T}$ lymphocytes from normal subjects or patients with autoimmune diseases in a dose dependent manner. Previous studies have shown that the inhibition of proliferation caused by exposure of stimulated lymphocytes to agents such as $N$-methyl$N$-nitrosourea or ionising radiation is an index of the cytotoxicity of these agents. ${ }^{78}$ In our study $T$ lymphocytes from patients with $R A$ and SLE were more hypersensitive to the cytotoxic effects of $\mathrm{H}_{2} \mathrm{O}_{2}$ than lymphocytes from healthy controls. Of the autoimmune diseases studied, scleroderma was exceptional in showing normal sensitivity of $\mathrm{T}$ lymphocytes to $\mathrm{H}_{2} \mathrm{O}_{2}$. Interestingly, previous studies with alkylating agents also showed that scleroderma lymphocytes showed a normal degree of sensitivity. ${ }^{7}$ The significant differences in the $\mathrm{H}_{2} \mathrm{O}_{2}$ toxicity curves of lymphocytes from patients with autoimmune diseases compared with healthy controls might indicate increased susceptibility to genotoxic damage resulting from defective DNA repair. Although the concentrations of $\mathrm{H}_{2} \mathrm{O}_{2}$ at which differential effects were achieved were relatively high, it should be noted that a significant proportion of the $\mathrm{H}_{2} \mathrm{O}_{2}$ added to the lymphocyte culture medium as a single bolus was probably destroyed before reaching its site of cytotoxic action within the cell.

In this study we found no significant relation of either cellular sensitivity to $\mathrm{H}_{2} \mathrm{O}_{2}$, or levels of 8-oxodG with disease duration, disease severity, sex, age, or drug treatment. This suggests that the differences described here, between lymphocytes from healthy and patient donors, were not simply a consequence of the disease process. Lymphocyte hypersensitivity to oxidative stress and increased levels of DNA damage in autoimmune diseases might be associated with lack of proficiency in repair of DNA damage. It has been proposed that defective DNA repair and hypersensitivity to a wide range of genotoxic agents predisposes subjects to the development of autoimmune diseases through somatic mutation. ${ }^{57}$ Therefore, further studies of the proficiency of 8-oxodG repair in human cells are warranted, particularly in autoimmune diseases.

This work was supported by the Arthritis and Rheumatism Council for Research, the British Technology Group, and The Royal London Hospital Trust. We thank Dr C Black, at the rheumatology department, Royal Free Hospital, for providing blood samples from patients with scleroderma, and providing blood samples from patients with scleroderma, and
Dr J Holmes, at the Hill Centre, The London Hospital Medical College, for statistical advice.

1 Tala N, Roubinian J R, Shear H, Hom J T, Miyasaka N. Progress in the mechanisms of autoimmune disease. In: Fougereau M, Dausset J, eds. Fourth international congress of immunology-80: Progress in immunology IV. London: Academic Press, 1980: 890-904.

2 McDevitt H O, Engleman E G. Association between genes in the major histocompatibility complex and disease susceptibility. Arthritis Rheum 1977; 20 (suppl): 9-20.

3 Dixon F J. Murine SLE-its implications for human diseases of autoimmunity. In: Weigle W O, ed. Advances in immunopathology. London: Edward Arnold, 1977: in immun $197-230$.

4 Burnet $M$. The clonal selection theory of acquired immunity. Cambridge: Cambridge University Press, 1959.

5 French D L, Laskov R, Scharff M. The role of somatic hypermutation in the generation of antibody diversity. Science 1989; 244: 1152-7.

6 Diamond B, Scharff M D. Somatic mutation of the T15 heavy chain gives rise to an antibody with autoantibody specificity. Proc Natl Acad Sci USA 1984; 81: 5841-4.

7 Lawley P D, Topper R, Denman A M, Hylton W, Hill I D, Harris G. Increased sensitivity of lymphocytes from patients with systemic autoimmune diseases to DNA alkylation by the methylating carcinogen N-methylalkylation by the methylating carcinogen $\mathrm{N}-$
$\mathrm{N}$-nitrosourea. Ann Rheum Dis 1988; 47: 445-51.

8 Harris G, Cramp W A, Edwards J C, et al. Radiosensitivity of peripheral blood lymphocytes in autoimmune disease. Int $\mathcal{f}$ Radiat Biol 1985; 47: 689-99.

9 Harris G, Asbery L, Lawley P D, Denman A M, Hylton W. Defective repair of $O^{6}$-methylguanine in autoimmune diseases. Lancet 1982; ii: 952-6.

10 Carson D A, Seto S, Wasson D B. Lymphocyte dysfunction after DNA damage by toxic oxygen species: a model of immunodeficiency. $\mathcal{F}$ Exp Med 1986; 163: 746-51.

11 Carson D A, Seto S, Wasson D B, Carrera C J. DNA strand breaks, NAD metabolism, and programmed cell death. Exp Cell Res 1986; 164: 273-81.

12 Schraufstatter I, Hyslop P A, Jackson J H, Cochrane C G. Oxidant-induced DNA damage of target cells. $\mathcal{f}$ Clin Invest 1988; 82: 1040-50.

13 Schraufstatter I, Hinshaw D B, Hyslop P A, Spragg R G, Cochrane C G. Oxidant injury of cells: DNA strandbreaks activate polyadenosine diphosphate-ribose polymerase and lead to depletion of nicotinamide adenine dinucleotide. f Clin Invest 1986; 77: 1312-20.

14 Ames B N, Gold L S. Chemical carcinogenesis: too many rodent carcinogens. Proc Natl Acad Sci USA 1990; 87: rodent carc $7772-6$.

15 Richter C, Park J, Ames B N. Normal oxidative damage to mitochondrial and nuclear DNA is extensive. Proc Natl Acad Sci USA 1988; 85: 6465-7.

16 Floyd $\mathrm{R} A$. The role of 8-hydroxyguanosine in carcinogenesis. Carcinogenesis 1990; 11: 1447-50.

17 Lunec J, Blake D R. Oxidative damage and its relevance to inflammatory joint disease. In: Chow $\mathrm{C} \mathrm{K}$, ed. Cellular antioxidant defence mechanisms. Vol III. Boca Raton: CRC Press, 1988: 143-59.

18 Halliwell B, Gutteridge J M C. Free radicals in biology and medicine. Oxford: Clarendon Press, 1989.

19 Kasai H, Nishimura S. DNA damage induced by asbestos in the presence of hydrogen peroxide. Gann 1984; 75: in the pres.

20 Aruoma O I, Halliwell B, Gajewski E, Dizdaroglu M. Damage to the bases in DNA induced by hydrogen peroxide and ferric ion chelates. $\mathcal{F}$ Biol Chem 1989; 264: 20509-12.

21 Aruoma O I, Halliwell B, Gajewski E, Dizdaroglu $M$. Copper-ion dependent damage to the bases in DNA in the presence of hydrogen peroxide. Biochem $\mathcal{F} 1991 ; 273$ : $601-4$.

22 Kuchino Y, Mori F, Kasai H, et al. Misreading of DNA templates containing 8-hydroxydeoxyguanosine at the modified base and at adjacent residues. Nature 1987; 327: 77-9. 
23 Kohda $\mathrm{K}$, Tada $M$, Kasai $H$, Nishimura S, Kawazoe Y Formation of 8-hydroxyguanine residues in cellular DNA exposed to the carcinogen 4-nitroquinoline-1-oxide. Biochem Biophys Res Commun 1986; 139: 626-32.

24 Fiala E S, Conaway C C, Mathis J E. Oxidative DNA and RNA damage in the livers of Sprague-Dawley rats treated with the hepatocarcinogen 2-nitropropane. Cancer Res 1989; 49: 5518-22.

25 Unemura T, Sai K, Takagi A, Hasegawa R, Kurokawa Y Formation of 8-hydroxydeoxyguanosine (8-OHdG) in rat kidney DNA after intraperitoneal administration of ferric nitrilotriacetate (Fe-NTA). Carcinogenesis 1990; 11: ferric nitr

26 Floyd $\mathrm{R} \mathrm{A}$, Watson $\mathrm{J} \mathrm{J}$, Wong $\mathrm{P} \mathrm{K}$, Altmiller $\mathrm{D} \mathrm{H}$ Rickard R C. Hydroxyl free radical adduct of deoxyguanosine: sensitive detection and mechanisms of formation. Free Radic Res Commun 1986; 1: 163-72.

27 Jeggo P. Isolation and characterization of $E$ coli K12 mutants unable to induce the adaptive response to simple alkylating agents. 7 Bacteriol 1979; 139: 783-91.

28 Tan E M, Cohen A S, Fries J F, et al. The 1982 revised criteria for the classification of systemic lupus erythematosus. Arthritis Rheum 1984; 25: 1271-7.

29 Hollingworth P, de Vere Tyndall A, Ansell B M, et al. Intensive immunosuppression versus prednisolone in the treatment of connective tissue diseases. Ann Rheum Dis 1982; 41: 557-62.

30 Ropes M W, Bennett G A, Cobb S, Jacox R, Jessar R A Revision of diagnostic criteria for rheumatoid arthritis. Bull Rheum Dis 1958; 9: 175-6.

31 Mason R M, Barnes C G. Behçet's syndrome with arthritis. Ann Rheum Dis 1969; 28: 95-103.

32 Masi A T, Rodnan G P, Medsger T A. Preliminary criteria for the classification of systemic sclerosis (scleroderma) Arthritis Rheum 1980; 23: 581-90.

33 Kirby K S. New methods for isolation of deoxyribonucleic acids: evidence on the nature of bonds between
deoxyribonucleic acid and protein. Biochem 7 1957; 66: deoxyribonu.

34 Beland F A, Dooley K L, Casciano D A. Rapid isolation of carcinogen bound DNA and RNA by hydroxyapatite chromatography. f Chromatogr 1979; 174: 177-86.

35 Winyard P G, Perrett D, Blake D R, Harris G, Chipman $\mathrm{J}$ K. Measurement of DNA oxidation products. Analytical Proceedings 1990; 27: 224-7.

36 Kasai $\mathrm{H}$, Nishimura $\mathrm{S}$. Detection and identification of mutagens and carcinogens as their adducts with muanosine derivatives. Nucleic Acids Res 1984; 12: guanosine

37 Harris G, Lawley P D, Olsen I. Mode of action of methylating carcinogens: comparative studies of murin and human cells. Carcinogenesis 1981; 1: 403-11.

38 Elgin R P, Lehner T, Subak-Sharpe J H. Detection of RNA complementary to Herpes-simplex virus in mononuclear cells from patients with Behçet's syndrome and recurren oral ulcers. Lancet 1982; ii: 1356-60.

39 Bhusate L L, Herbert K E, Scott D L, Perrett D. Increased DNA strand breaks in mononuclear cells from patients with rheumatoid arthritis. Ann Rheum Dis 1992; 51: with.

40 Shibutani S, Takeshita M, Grollman A P. Insertion of specific bases during DNA synthesis past the oxidation damaged base 8-oxodG. Nature 1991; 349: 431-4.

41 Kasai H, Crain P F, Kuchino Y, Nishimura S Ootsuyama A, Tanooka H. Formation of 8-hydroxy- guanine moiety in cellular DNA by agents producing oxygen radicals and evidence for its repair. Carcinogenesis 1986; 7: 1849-51.

42 Chung $M$ H, Kasai H, Jones D S, et al. An endonuclease activity of $E$. coli that specifically removes 8-hydroxyguanine residues from DNA. Mutat Res 1991; 254: 1-12.

43 Chung M H, Kim H S, Ohtsuka E, Kasai H, Yamamoto F, Nishimura S. An endonuclease activity in human polymorphonuclear neutrophils that removes 8-hydroxyguanine residues from DNA. Biochem Biophys Res Commun 1991; 178: 1472-8.

44 Hoebee B, Brouwer J, Van de Putte P, Loman H, Retel J. Cobalt 60 gamma-rays induce predominantly $\mathrm{C} / \mathrm{G}$ to $\mathrm{G} / \mathrm{C}$ transversions in double-stranded M13 DNA. Nucleic Acids Res 1988; 16: 8147-56.

45 Kiyosawa H, Murata K, Aota $M$, et al. Detection of 8-hydroxydeoxyguanosine in human lymphocyte DNA In: Hayaishi O, Niki E, Kondo M, Yoshikawa T, eds Medical, biochemical and chemical aspects of free radicals. Amsterdam: Elsevier, 1989: 1511-2.

46 Malins D C, Haimanot R. Major alterations in the nucleotide structure of DNA in cancer of the female breast. Cancer Res 1991; 51: 5430-2.

47 Floyd R A, Watson J J, Harris J, West M, Wong P K Formation of 8-hydroxydeoxyguanosine, hydroxyl free radical adduct of DNA in granulocytes exposed to the tumour promoter, tetradeconylphorbolacetate. Biochem Biophys Res Commun 1986; 137: 841-6.

48 Fraga C G, Shigenaga M K, Park J W, Degan P, Ames B N. Oxidative damage to DNA during aging: 8-hydroxy-2'-deoxyguanosine in rat organ DNA and urine. Proc Natl Acad Sci USA 1990; 87: 4533-7.

49 Kiyosawa Y, Suko M, Okidaira H, et al. Cigarette smoke induces formation of 8-hydroxydeoxyguanosine, one of the oxidative DNA damages in human peripheral leukocytes. Free Radic Res Commun 1990; 11: 23-7.

50 Emerit I, Michelson A M. Chromosome instability in human and murine autoimmune disease: anticlastogenic effect of superoxide dismutase. Acta Physiol Scand 1980 suppl 492: 59-65.

51 Weitberg A B, Weitzman S A, Destrempes M, Latt S A Stossel T P. Stimulated human phagocytes produce cytogenetic changes in cultured mammalian cells. $N$ Engl f Med 1983; 308: 26-9.

52 Chong Y C, Heppner G H, Paul L A, Fulton A $M$ Macrophage-mediated induction of DNA strand breaks in target tumour cells. Cancer Res 1989; 49: 6652-7.

53 Jackson J H, Gajewski E, Schraufstatter I U, et al. Damage to the bases in DNA induced by stimulated human to the bases in DNA induced by stim

54 Winyard P G, Faux S P, Smith A J, Davies J E Chipman J K. Bleomycin-induced unscheduled DNA synthesis in non-permeabilised human and rat hepatocytes is not paralleled by 8-oxo-7-hydrodeoxyguanosine formation. Biochem Pharmacol 1992; 44: 1255-60.

55 Dizdaroglu M, Nackerdien Z, Chao B, Gajewski E, Rao G. Chemical nature of in vivo DNA base damage in hydrogen peroxide-treated mammalian cells. Arch Biochem Biophys 1991; 285: 388-90.

56 Blount $S$, Lunec J, Griffiths $H$, Emery $P$, Jackson J, Cochrane C. 8-Hydroxydeoxyguanosine: a marker of oxygen radical damage to DNA in systemic lupus. $\mathrm{Br} \mathcal{F}$ oxygen radical damage to DNA
Rheumatol 1991; 30 (suppl 2): 50 .

57 Harris G. DNA damage and repair of immunologically active cells. Immunol Today 1983; 4: 109-12. 